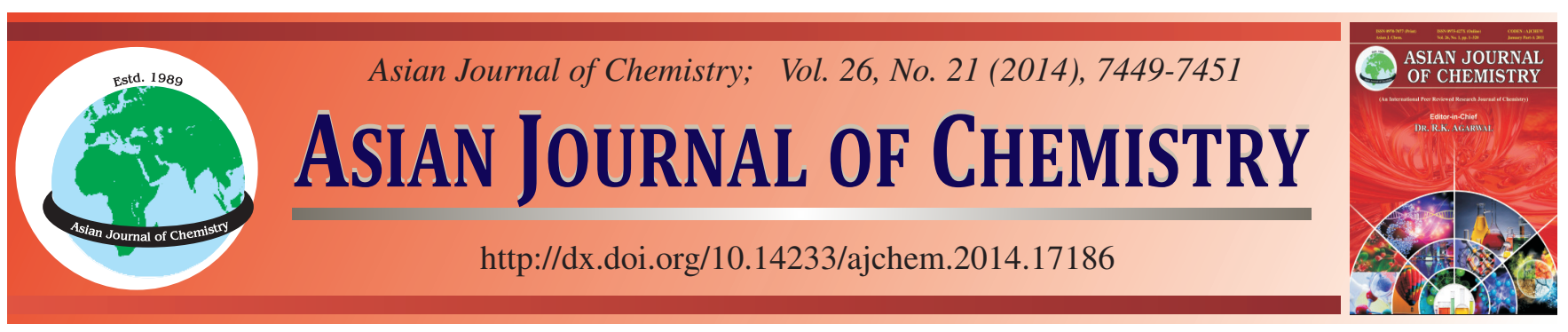

\title{
Synthesis and Antitumor Activities of Some 2-Oxo-quinoline-3-Schiff Base Derivatives
}

Yilin Fang ${ }^{1}$, XiAnghui $\mathrm{Y}^{2}$, Wen Qin ${ }^{2}$, Ye Zhang ${ }^{2, *}$ and YongZhi LiaO ${ }^{3, *}$

${ }^{1}$ College of Chemistry and Chemical Engineering, Hunan University, Hunan 410082, P.R. China

${ }^{2}$ Department of Chemistry, Guilin Normal College, Guangxi 541001, P.R. China

${ }^{3}$ Guangxi Academy of Fishery Sciences, Nanning 530021, P.R. China

*Corresponding authors: Fax: +86 77 32806321; Tel: +86 77 32823285; E-mail: zhangye81@ 126.com; liao0777@163.com

A series of 2-oxo-quinoline-3-Schiff-base derivatives $\left(\mathbf{4} \mathbf{a}_{1}-\mathbf{4} \mathbf{n}_{2}\right)$ have been designed and synthesized as new antitumor agents. in vitro
Antitumor activities were evaluated against four cancer cell lines including MGC80-3, BEL-7404, A549 and NCI-H460. Compounds $\mathbf{4} \mathbf{a}_{1}$,
$\mathbf{4 a}_{2}, \mathbf{4 c}_{2}, \mathbf{4 d}_{1}, \mathbf{4 d}_{\mathbf{2}}$ and $\mathbf{4 l}_{2}$ exhibited better inhibition activities than commercial antitumor drug 5-fluorouracil $\left(5\right.$-fluorouracil, IC $C_{50}=44 \pm$
$0.54 \mu \mathrm{M})$ on NCI-H460, with $\mathrm{IC}_{50}$ of $35.52 \pm 0.86,16.22 \pm 0.71,11.62 \pm 0.52,5.16 \pm 0.37,7.62 \pm 0.46$ and $7.66 \pm 0.65 \mu \mathrm{M}$, respectively.

Keywords: 2-Oxo-quinoline-3-Schiff-base derivatives, Synthesis, Antitumor activity.

ᄂ - - - - - - - - - - - - - - - - - - - - - - - - - -

\section{INTRODUCTION}

Cancer is one of the primary causes of death globally, so searching and screening for effective new anticancer drugs have greatly attracted bioorganic chemists' interest. Antioxidants are recently fabricated as the drug candidates to counter multifarious diseases, such as carcinogenesis, inflammation, atherogenesis and aging in aerobic organisms ${ }^{1,2}$. Therefore, screening for new antitumor drug from antioxidants has become an important research topic in bioinorganic chemistry.

Quinoline and its derivatives displays extensively biological and pharmacological activities ${ }^{3-6}$ so a great deal of efforts have been devoted to design and synthesize functional quinoline derivatives with better medicinal virtue over the past decades. 2-Oxo-quinoline is a kind of alkaloid and widely exists in nature as same as quinoline. Researchers have long explored natural products in the search for new antioxidants and anticancer drugs, so those compounds with a 2-oxoquinoline structure core have been studied and it have been found that they own preferable biological activities such as antioxidation, anticancer, antiproliferation and antiinflammation $^{7-10}$. In our previous work, some 2-oxo-quinoline-3schiff-base derivatives $\left(\mathbf{4} \mathbf{a}_{1}-\mathbf{4} \mathbf{n}_{2}\right)$ (Scheme-I) have been demonstrated to have good antioxidant. Since antioxidants have been recently forged as the anticancer drug candidates, so the aim of the present work is to evaluate the in vitro antitumor activities of compounds $\mathbf{4} \mathbf{a}_{\mathbf{1}}-\mathbf{-} \mathbf{n}_{\mathbf{2}}$, employing standard MTT assay.

\section{EXPERIMENTAL}

2-Oxo-quinoline-3-Schiff-base derivatives $\mathbf{4} \mathbf{a}_{\mathbf{1}}-\mathbf{- 4} \mathbf{n}_{\mathbf{2}}$ were synthesized as outlined in Scheme-I, accoding to the literature $^{11}$. Quinoline carbaldehydes (2) were got through VilsmeierHaack-Arnold reaction, which is subjected the condensation of acetanilides (1) with N,N-dimethylformamide (DMF) in the presence of phosphorus oxychloride. Compounds $\mathbf{3}$ were then obtained in good yields by the hydrolytic reaction of compound 2 in the presence of $70 \%$ acetic acid aqueous solution. Compounds $\mathbf{4} \mathbf{n}_{\mathbf{1}} \mathbf{-} \mathbf{4} \mathbf{n}_{\mathbf{2}}$ were then gained in good yields by the condensation of compound $\mathbf{3}$ with different primarily amines or hydraziniums in hot ethanol, respectively.

The in vitro antitumor activities of compound $\mathbf{4} \mathbf{a}_{\mathbf{1}}-\mathbf{- 4} \mathbf{n}_{\mathbf{2}}$ were evaluated by a MTT assay ${ }^{12,13}$ on four typical human cancer cell lines (5-fluorouracil as the positive control), including stomach cancer cell MGC80-3, liver cancer cell BEL-7404, lung cancer cell A549 and lung cancer cell NCI-H460. Firstly, the in vitro antitumor activity initial screening test was done by the respective condensation of $20 \mu \mathrm{M}$ of compounds $\mathbf{4} \mathbf{a}_{\mathbf{1}}-\mathbf{- 4} \mathbf{n}_{\mathbf{2}}$ with these cancer cells, respectively.

\section{RESULTS AND DISCUSSION}

As shown in Table-1, compounds $\mathbf{4} \mathbf{c}_{2}, \mathbf{4 g}_{\mathbf{2}}-\mathbf{4} \mathbf{i}_{\mathbf{2}}, \mathbf{4} \mathbf{k}_{\mathbf{2}}, \mathbf{4} \mathbf{l}_{2}$, $\mathbf{4 m}_{\mathbf{1}}, \mathbf{4} \mathbf{n}_{\mathbf{1}}$ and $\mathbf{4} \mathbf{n}_{\mathbf{2}}$ showed none inhibition on stomach cancer cell MGC80-3, while other compounds displayed weak inhibition on this cancer cell. Of these compounds, compound $\mathbf{4} \mathbf{a}_{2}$ exhibited the best inhibition on stomach cancer cell MGC803 , with a mere inhibition rate $26.21 \%$. In the lung cancer cell 


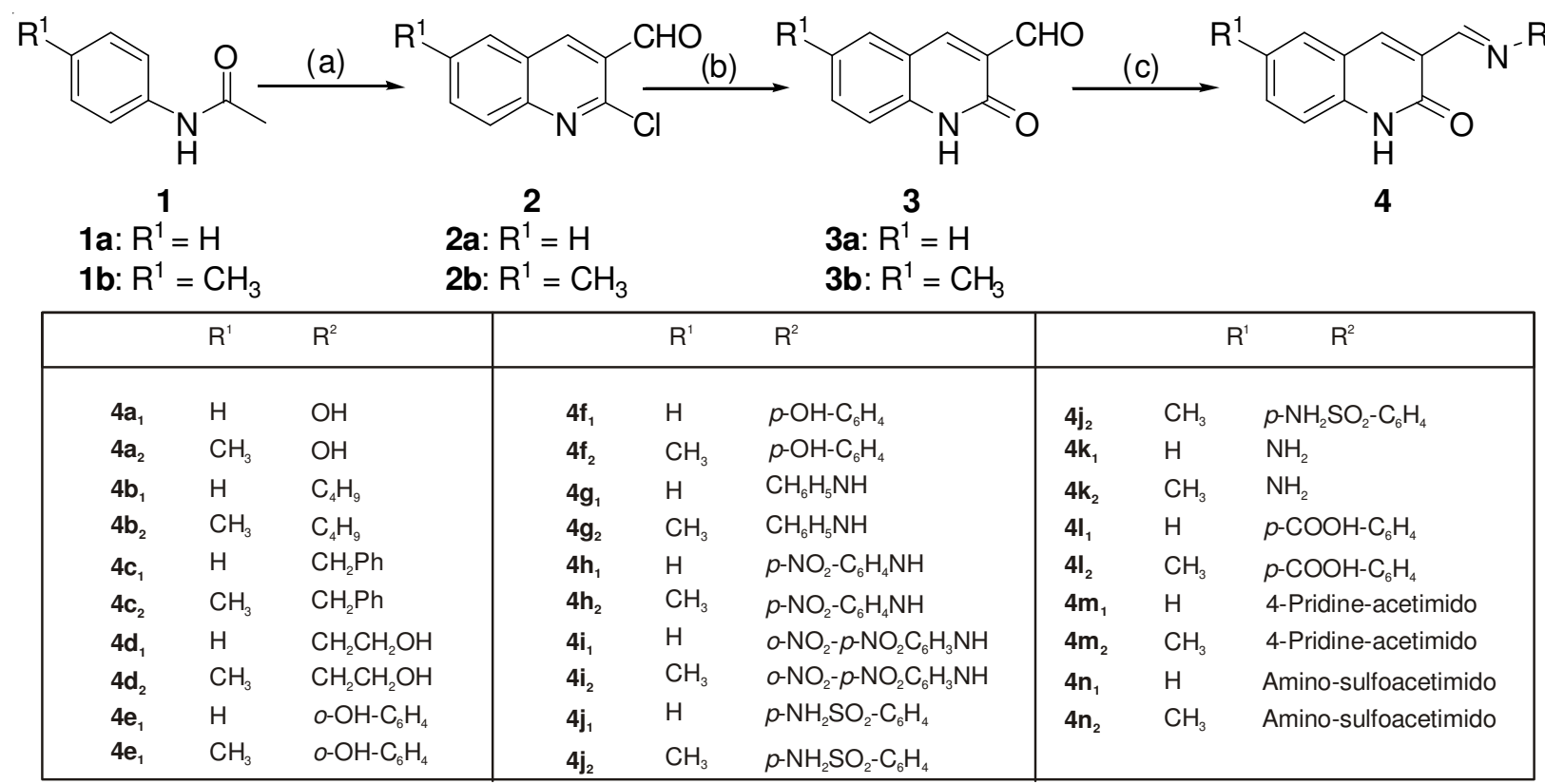

Scheme-I: Synthetic route of 2-oxo-quinoline-3-carbaldehyde schiff-base derivatives. Reagents and conditions: (a) $\mathrm{DMF} / \mathrm{POCl}{ }_{3}, 90{ }^{\circ} \mathrm{C}$; (b) $70 \%$ acetic acid aqueous solution, $95{ }^{\circ} \mathrm{C}$; (c) $\mathrm{R}_{2}-\mathrm{NH}_{2}$, ethanol, $80{ }^{\circ} \mathrm{C}$

TABLE-1

INHIBITION RATES (\%) OF COMPOUNDS $\mathbf{4} \mathbf{a}_{\mathbf{1}}-\mathbf{4} \mathbf{n}_{\mathbf{2}}$ ON THE CANCER CELLS LINES. BOLD VALUES REPRESENT TO POINT OUT THE ACTIVE COMPOUNDS

\begin{tabular}{|c|c|c|c|c|}
\hline Entry & MGC80-3 & $\mathrm{A} 549^{\mathrm{b}}$ & NCI-H460' & BEL-7404 \\
\hline $\mathbf{4} \mathbf{a}_{1}$ & 19.37 & 15.99 & 45.64 & 23.59 \\
\hline $4 a_{2}$ & 26.21 & 11.27 & 50.26 & 14.51 \\
\hline $4 b_{1}$ & 9.79 & NA & 11.93 & 9.051 \\
\hline $4 b_{2}$ & 8.70 & NA & 20.52 & 14.68 \\
\hline $4 c_{1}$ & 15.85 & 10.51 & 23.61 & NA \\
\hline $4 c_{2}$ & NA & NA & 67.54 & 17.00 \\
\hline $4 d_{1}$ & 9.51 & 3.52 & 75.65 & 8.12 \\
\hline $\mathbf{4} d_{2}$ & 8.86 & 11.04 & 71.65 & 9.98 \\
\hline $4 e_{1}$ & 21.85 & 19.97 & NA & 6.48 \\
\hline $4 e_{2}$ & 15.34 & NA & NA & 5.94 \\
\hline $4 f_{1}$ & 8.33 & NA & NA & 10.74 \\
\hline $4 f_{2}$ & 21.94 & NA & 19.96 & 12.33 \\
\hline $4 g_{1}$ & 6.55 & NA & 4.22 & 15.05 \\
\hline $4 g_{2}$ & NA & NA & 11.27 & 24.51 \\
\hline $4 h_{1}$ & NA & NA & 9.97 & 7.35 \\
\hline $4 h_{2}$ & NA & NA & 29.42 & 12.28 \\
\hline $4 i_{1}$ & NA & NA & NA & NA \\
\hline $4 i_{2}$ & NA & NA & NA & 5.82 \\
\hline $4 j_{1}$ & 3.62 & 10.95 & NA & 3.51 \\
\hline $4 j_{2}$ & 4.54 & 5.95 & NA & 7.89 \\
\hline $4 k_{1}$ & 5.53 & 11.39 & NA & 11.18 \\
\hline $4 k_{2}$ & NA & 5.33 & NA & 12.34 \\
\hline $4 l_{1}$ & 8.58 & 1.73 & 22.02 & 12.46 \\
\hline $4 I_{2}$ & NA & 3.40 & 72.50 & 23.27 \\
\hline $4 m_{1}$ & NA & 10.88 & 9.49 & 8.53 \\
\hline $4 m_{2}$ & 12.25 & 4.53 & 12.37 & 10.38 \\
\hline $4 n_{1}$ & NA & 4.45 & NA & 13.15 \\
\hline $4 n_{2}$ & NA & 8.41 & 11.28 & 5.34 \\
\hline
\end{tabular}

A549 assay, compounds $\mathbf{4} \mathbf{b}_{1}, \mathbf{4 b}_{\mathbf{2}}, \mathbf{4} \mathbf{c}_{2}$ and $\mathbf{4} \mathbf{e}_{2}-\mathbf{4} \mathbf{i}_{2}$ did not show any inhibition on this lung cancer cell and compounds $\mathbf{4} \mathbf{a}_{\mathbf{1}}$, $\mathbf{4} \mathbf{a}_{\mathbf{2}}, \mathbf{4} \mathbf{c}_{\mathbf{1}}, \mathbf{4} \mathbf{d}_{\mathbf{1}}-\mathbf{4} \mathbf{e}_{\mathbf{1}}$ and $\mathbf{4} \mathbf{j}_{\mathbf{1}}-\mathbf{4} \mathbf{n}_{\mathbf{2}}$ also exhibited low inhibition on it. Compound $\mathbf{4} \mathbf{e}_{\mathbf{1}}$ displayed the best inhibition effect in this assay, with inhibition rate $(19.97 \%)$ of less than $20 \%$. For liver cancer cell BEL-7404 assay, all the compounds except $\mathbf{4} \mathbf{c}_{1}$ and $\mathbf{4} \mathbf{i}_{1}$ exhibited inhibition on this kind of cancer cell. Compound $\mathbf{4 g}_{2}$ showed the highest inhibition on liver cancer cell BEL-7404, with a low inhibition rate of $24.51 \%$. In the lung cancer cell NCI-H460 test, compounds $\mathbf{4} \mathbf{e}_{\mathbf{1}}-\mathbf{4} \mathbf{f}_{\mathbf{1}}, \mathbf{4} \mathbf{i}_{\mathbf{1}}-\mathbf{4} \mathbf{k}_{\mathbf{2}}$ and $\mathbf{4} n_{1}$ showed none inhibition activities on this cancer cell, while other compounds showed various inhibition rates in this assay. It was worthy to note that six compounds $\mathbf{4} \mathbf{a}_{1}, \mathbf{4} \mathbf{a}_{2}, \mathbf{4} \mathbf{c}_{2}$, $\mathbf{4 d}_{\mathbf{1}}, \mathbf{4 d}_{\mathbf{2}}$ and $\mathbf{4 l}_{\mathbf{2}}$ exhibited better inhibition on lung cancer cell NCI-H460, with desirable inhibition rates of 45.64, 50.26, $67.54,75.65,71.65$ and $72.50 \%$, respectively. Therefore, these six compounds were selected to do the further in vitro antitumor activity to test against lung cancer cell NCI-H460 and their IC $_{50}$ values were thus determined (Table-2). $\mathrm{IC}_{50}$ of the classic antitumor drug 5-fluorouracil was also determined for comparison.

As shown in Table-2, $\mathrm{IC}_{50}$ of $\mathbf{4 a}_{\mathbf{1}}, \mathbf{4} \mathbf{a}_{2}, \mathbf{4 c}_{2}, \mathbf{4 d}_{\mathbf{1}}, \mathbf{4 d}_{\mathbf{2}}, \mathbf{4} \mathbf{l}_{\mathbf{2}}$ and 5-fluorouracil in lung cancer cell NCI-H460 assay were found to be $35.52 \pm 0.86,16.22 \pm 0.71,11.62 \pm 0.52,5.16 \pm$ $0.37,7.62 \pm 0.46,7.66 \pm 0.65$ and $44 \pm 0.54 \mu \mathrm{M}$, respectively. Markedly, these six compounds exhibited better antitumor activity than the commercial antitumor drug 5-fluorouracil. It was important to note that compounds $\mathbf{4 d}_{\mathbf{1}}, \mathbf{4}_{\mathbf{2}}$ and $\mathbf{4 l}_{\mathbf{2}}$ showed excellent antitumor activity, with $\mathrm{IC}_{50}$ even lower than $10 \mu \mathrm{M}$. Obviously, the antitumor activity decreased in the order $\mathbf{4} \mathbf{d}_{\mathbf{1}}$, $\mathbf{4 d}_{2}, \mathbf{4 l}_{2}, \mathbf{4}_{2}, \mathbf{4} \mathbf{a}_{2}, \mathbf{4} \mathbf{a}_{1}, 5$-fluorouracil. The order indicated that methyl group on quinoline skeleton and hydroxyl groups

\begin{tabular}{cccccccc} 
Entry & $\mathbf{4 a}_{\mathbf{1}}$ & $\mathbf{4 a}_{\mathbf{2}}$ & $\mathbf{4}_{\mathbf{2}}$ & $\mathbf{4 d}_{\mathbf{1}}$ & $\mathbf{4 d}_{\mathbf{2}}$ & $\mathbf{4 l}_{2}$ & 5-Fluorouracil \\
\hline NCI-H460 & $35.52 \pm 0.86$ & $16.22 \pm 0.71$ & $11.62 \pm 0.52$ & $5.16 \pm 0.37$ & $7.62 \pm 0.46$ & $7.66 \pm 0.65$ & $44.0 \pm 0.54$ \\
\hline
\end{tabular}


linked with salen group may have important effect on their antitumor activities.

In conclusion, on the base of above observation, it could be concluded that screening for new antitumor drug from 2oxo-quinoline-3-Schiff-base derivatives $\mathbf{4} \mathbf{a}_{\mathbf{1}}-\mathbf{4} \mathbf{n}_{\mathbf{2}}$ is feasible.

\section{ACKNOWLEDGEMENTS}

This study was supported by the Fund of Guangxi Key Laboratory of Functional Phytochemicals Research and Utilization (No. FPRU2011-6; FPRU2013-6), the State Key Laboratory Cultivation Base for the Chemistry and Molecular Engineering of Medicinal Resources, Ministry of Science and Technology of China (CMEMR2014-B14), the Guangxi Natural Science Foundation (No. 2014GXNSFBA118050) and Guangxi Department of Education Research Project (No. 2013YB283; 2013YB284).

\section{REFERENCES}

1. B.N. Ames, M.K. Shigenaga and T.M. Hagen, Proc. Natl. Acad. Sci. USA, 90, 7915 (1993).

2. Y.K. Tyagi, A. Kumar, H.G. Raj, P. Vohra, G. Gupta, R. Kumari, P. Kumar and R.K. Gupta, Eur. J. Med. Chem., 40, 413 (2005).
3. K. Iwasa, M. Moriyasu, Y. Tachibana, H. Kim, Y. Wataya, W. Wiegrebe, K.F. Bastow, L.M. Cosentino, M. Kozuka and K. Lee, Bioorg. Med. Chem., 9, 2871 (2001).

4. D.L. Minor, S.D. Wyrick, P.S. Charifson, V.J. Watts, D.E. Nichols and R.B. Mailman, J. Med. Chem., 37, 4317 (1994).

5. R. Naito, Y. Yonetoku, Y. Okamoto, A. Toyoshima, K. Ikeda and M. Takeuchi, J. Med. Chem., 48, 6597 (2005).

6. J. Chen, X. Chen, M. Bois-Choussy and J. Zhu, J. Am. Chem. Soc., 128, 87 (2006).

7. J. DeRuiter, A.N. Brubaker, W.L. Whitmer and J.L. Stein, J. Med. Chem., 29, 2024 (1986).

8. P. Hewawasam, W. Fan, J. Knipe, S.L. Moon, C.G. Boissard, V.K. Gribkoff and J.E. Starrett Jr, Bioorg. Med. Chem. Lett., 12, 1779 (2002).

9. J. Rousell, E.B. Haddad, J.C. Mak, B.L. Webb, M.A. Giembycz and P.J. Barnes, Mol. Pharmacol., 49, 629 (1996).

10. I.V. Ukrainets, V.O. Gorokhova, A.P. Benzuglyi and V.L. Sidorenko, Farm. Zh., 1, 75 (2000).

11. Y. Zhang, B.Q. Zou, K. Wang, Y.M. Pan, H. Liang, X.H. Yi and H.S. Wang, Med. Chem. Res., 21, 1341 (2012).

12. S. Rubino, S. Petruso, R. Pierattelli, G. Bruno, G.C. Stocco, L. Steardo, M. Motta, M. Passerotto, E.D. Giudice and G. Gulì, J. Inorg. Biochem., 98, 2071 (2004).

13. M. Botta, S. Armaroli, D. Castagnolo, G. Fontana, P. Pera and E. Bombardelli, Bioorg. Med. Chem. Lett., 17, 1579 (2007). 